\title{
Influencing External Factors for Small Arms Light Weapon Smuggling at Malaysia-Thailand Border
}

\author{
Rafidah Dahari ${ }^{1}$, Nor Azizan Idris ${ }^{2} \&$ Zarina Othman ${ }^{2}$ \\ ${ }^{1} \mathrm{PhD}$ Candidate from the Strategic \& Security Program, Department of History, Politics and Strategy, Faculty of \\ Social Sciences and Humanities, National University of Malaysia, UKM Bangi, Selangor Darul Ehsan, Malaysia \\ ${ }^{2}$ Associate Professors from the Strategic \& Security Program, Department of History, Politics and Strategy, \\ Faculty of Social Sciences and Humanities, National University of Malaysia, UKM Bangi, Selangor Darul Ehsan, \\ Malaysia \\ Correspondence: Nor Azizan Idris. E-mail: nai@ukm.edu.my
}

Received: January 7, 2019

Accepted: January 28, 2019

Online Published: February 28, 2019

doi:10.5539/ass.v15n3p14

URL: https://doi.org/10.5539/ass.v15n3p14

\begin{abstract}
End of the Cold War had contributed to the plentitude of firearms within the Southeast Asia region which led to the increase of small arms and light weapon (SALW) smuggling activity. For decades till today, most countries in this region continue to face internal armed conflicts. Malaysia strategic location, situated at the world's busiest sea lane trades had resulted in rampant cross border crime of SALW smuggling activities. Malaysia's strict firearms law disallows the possession of SALW without a license. In spite of such strict SALW legislations, these smugglings continues. What are the factors that contribute to the increase of SALW smuggling into Malaysia? The main objective of this article is to scrutinise the external factors that promote the increase of SALW smuggling into Malaysia. This study employs a qualitative method with primary data obtained through preliminary and formal interviews with Malaysian and Thailand security agencies, crime desk journalist, non-governmental organizations, smugglers, former separatist member, former Thai residents, informers and prisoners of SALW related. Whilst secondary data was acquired via credible research. The study found that the national factors and non-national factors have influenced the increase of SALW smuggling into Malaysia.
\end{abstract}

Keywords: globalization, cross-border crimes, SALW smuggling, definition of SALW, influencing external factors

\section{Introduction}

Post Cold War had witnessed a distinct shift within the security spectrum from direct military threats to that of non-military. This borderless environment compounded with the effects of globalization have made border more porous that permit free flow human and trading traffic within this shrinking geographical space. The reality of globalization has brought about profound impact however its contribution to mankind had not been limited. (Khoo \& Jomo, 2002). McGrew \& Lewis (1992, p. 65) expounds that with the increase in cross border connectivity whether it be personal relations, institutional demands, air travel or communications systems, on the same vein such extensive cross border movements equally offer similar opportunities for crime, environmental damage, drug smugglings, immigration and many others have direct consequences that could undermine the peace and stability of a nation. As argued by Williams \& Black (1994, p. 127), collectively echoed by other renowned analyst have categorized such Post Cold War security threat to respective nation's threat outlook and international order within the concept of Gray Area Phenomenon. The momentum towards this concept has slowly grown to engulf conflicts as ethno-religious-nationalistic, proliferation weapons of mass destruction and advanced delivery capabilities; hunger; engaging conflicts with limited resources; the spread of epidemics as in AIDS and other infectious diseases; globalization of organized crime; widespread use of drugs; economic warfare and conflicts with technology; and large migrations of the population including political asylums and economic refugees.

This has indirectly promulgated a shift in the focus of security not only on threats that can jeopardize the political survival and territorial integrity of a country but additionally how these threats may directly impact upon the safety of its people and upset national security. Emmers (2003, p. 421) in agreeing, cited the words of Galeotti (2001, p. 216) that "the struggle against organized and transnational crime will be the defining security 
concern of the twenty-first century". The United Nations (UN) has rather conclusively defined cross-border crimes (CBC) as an offence that acts as a springboard for other more wrongs. Its prevention and / or influence whether directly or indirectly compels the participation of more than one nation (Emmers 2003, p. 420). In the era of globalization, a large variety of trade activities are undertaken within borderless circumstances. This phenomenon has pushed the boundaries of open space and indirectly opened the door for firearm smuggling. Within Southeast Asia, firearm smuggling has since emerged as a prized trade in CBC. As argued by Lumpe, Meek and Naylor (2000, p. 2), firearm smuggling is believed to be the second highest commodity smuggled after drugs.

Kramer (2001, p. 2) in concurring did not offer any disagreement that the issue of small and light weapons (SALW) is almost always connected with CBC. However the issue of CBC is often immersed into the overall security agenda to combat other more pressing cross border issues that are accorded more precedence as in drug trafficking and human trafficking. Kramer equally argued that the issue of smuggling and the problems related to SALW are often relegated and marginalized as little apprehension is dwelled into how these SALW are legitimately produced, transported, transfers and ownership processed with its entry into the black market.

Within the global context, the abuse of SALW in most countries is one of the leading causes of death and injury. Evoy \& Hideg (2017, p. 49) in their Small Arms Survey Report deduced globally in 2016, 44\% of the deaths were due to the use of SALW. Total deaths due to SALW rose from 171,000 in 2004 to 210,000 people in 2016. From that total, approximately $15 \%$ individual deaths are due to direct conflict whilst $81 \%$ are victims of organized killings (Evoy \& Hideg, 2017, p. 49). The Small Arms Survey Report also estimates a total of 875 million small arms weapons hovering around the world and are produced by more than 1,000 companies that are plying this trade in more than 100 countries. According to Spapens (2007, p. 361), it is estimated that 5 percent of the total world's legal firearm sales amounting to more than USD8.5 billion are illegal sales. Most of the firearms that are traded illegally are within this SALW bracket. The annual volume of illegal firearm trade could easily amount to two or three billion dollars. Stohl $(2005$, p. 61$)$ research indicates that a global firearm legal market is estimated at USD4 billion a year of which the sale of illegal SALW is valued at almost USD1 billion.

The Small Arms Survey (2003, p. 130) in citing Cook and Ludwig (2002, p. 2) stated that firearms are more lethal than other weapons such as knives, batons and fists as it offers a distinct advantage to the attackers. With a little devotion, it offers the power to inflict a quick death from a distance and with the little use of strength. Death due to firearm violence remains high, seemed unbalanced as its abuse brings about more death than injuries. From Myanmar to Colombia, firearms are usually the weapons of choice in killings and armed conflicts. On the same vein, this deadly weapon would serve as a powerful tool to oppress the people and ensure compliance. The United Nations (UN) in 2001 through the United Nations (UN) Conference on the Illicit Trade in Small Arms and Light Weapons In All Its Aspects that convened in New York collectively endorsed that the ever availability and abuse of firearms are two acute challenges facing the international community today. Affected countries collectively agree that the flooding and wide dissemination of weapons minus any form of control in most parts of the world poses a serious threat to security, stability, sustainable development of individuals, communities, nations, regions and overall international environment.

Studies by Capie $(2002$, p. 1) and Stohl $(2005$, p. 60), indicate that since the end of the Cold War, exist a transition within the security context, a shift from armed inter-state confrontations to armed civil outbreaks within a country itself. In such armed surges, most of the lethal casualities are due to SALW as compared to conventional weapons. Capie research further contested that most of these SALW circulating in Southeast Asia are not new but recycled firearms (Capie, 2002, p. 104). Every year, between 50,000 to 100,000 people perish; become victims of SALW in 'low-level' conflict especially in deprived countries. However, the casuality rate in such destitute areas could be doubled due to the easy access to SALW (Markowski, Koorey and Brauer 2009: 171). Given this reality, the true figure of these firearms violences that resulted in the numerous killings and injured civilians in Southeast Asia is unknown. In the absence of any conclusive government records, statistics of the abuse of SALW is estimated with more than 15,300 registered murder cases. In short, though shattering, the current statistics of lethal cases due to SALW in Southeast Asia is incomplete and unreliable (Muggah \& Moser-Puangsuwan, 2003, p. 7). As stated by UN and Muggah and Moser-Puangsuwan and supported by Capie (2002, p. 10) and Griffiths (2010, p. 130), the ever availability supply of firearms following the demise of the Cold War more so with abundant quantity of SALW being a spillover from the former Soviet Union and East Block in the market inevitable offered enticing prospects market for prospective buyers. The unfavourable economic environment of reduced military spendings coupled with weak regulatory protocols indirectly compelled these countries with large abandoned stocks to ever available customers.

The Gunpolicy report offer similar findings as that by Muggah and Moser-Puangsuwan (2003) where fatal 
casualities due to SALW within the Southeast Asian region are rarely recorded especially in Indonesia, Laos, Malaysia, Myanmar, Thailand, Timor-Leste and Vietnam. In the 1990s, Thailand recorded the highest number of killings due to SALW throughout Asia (GunPolicy.Org). Data obtained from the University of Washington, attest to Thailand having the highest number of killings due to SALW, followed by Philippines. As in 2013, Thailand registered a death rate, killings due to abuse of SALW at a rate of 7:48 for every 100,000 people, which is twice as much, compared to the US. Subsequently findings published in the 2015 edition by The American Journal of Medicine Preventive indicate possession of SALW significantly contribute towards increase of terrorism in Thailand (Channel News Asia Online, 18 February 2016).

Deaths due to SALW in Southeast Asia for the period 2000 - 2012 are recorded at 167,093 as reported by the United Nations Office on Drugs and Crime (UNODC), demonstrated in Table 1 below. The Philippines has recorded the highest number with 87,532 cases followed by Thailand at 53,973 cases and Indonesia with 11,922 cases. There appear to be a vast difference when compared to other regional nations such as Myanmar (8044 cases), Vietnam (3037 cases), Cambodia (964 cases), Malaysia (652 cases), Laos (392 cases) and others regional countries that have a relatively very low recorded cases. This rather diverse difference could be due to lack of records or the absence of any official statistics or government records of such SALW cases as indicated by the Gunpolicy Report.

Table 1. Statistic of deaths due to SALW in Southeast Asia for the period 2000-2012

\begin{tabular}{|c|c|c|c|c|c|c|c|c|c|c|c|}
\hline Year & Brunei & Cambodia & Indonesia & Laos & Malaysia & Myanmar & Philippines & Singapore & Thailand & $\begin{array}{l}\text { Timor } \\
\text { Leste }\end{array}$ & Vietnam \\
\hline 2000 & & & 2204 & & & & 5735 & 37 & 5142 & & \\
\hline 2001 & & & & & & & 5852 & 30 & 5020 & & \\
\hline 2002 & & & & & & & 6553 & 22 & 4538 & & \\
\hline 2003 & & & 1635 & & & & 6436 & 24 & 6434 & & \\
\hline 2004 & & & 1419 & & & & 6344 & 21 & 4273 & 23 & \\
\hline 2005 & & & & & & & 6434 & 21 & 4806 & 46 & \\
\hline 2006 & & & & & & & 6196 & 17 & 4687 & 49 & \\
\hline 2007 & & & & & & & 5739 & 18 & 4435 & 62 & \\
\hline 2008 & & & 1372 & & & & 5820 & 27 & 3974 & 35 & \\
\hline 2009 & & & 1311 & & & & 6368 & 20 & 3703 & 32 & \\
\hline 2010 & & & 1058 & & & & 8897 & 19 & 3654 & 39 & \\
\hline 2011 & & & 1467 & & & & 8674 & 16 & 3307 & & \\
\hline 2012 & 8 & 964 & 1456 & 392 & 652 & 8044 & 8484 & 11 & - & & 3037 \\
\hline Total & 9 & 964 & 11922 & 392 & 652 & 8044 & 87532 & 283 & 53973 & 286 & 3037 \\
\hline
\end{tabular}

Source: United Nations Office on Drugs and Crime Homicide Statistics (2013)

Smuggling of SALW into Malaysia is not a new phenomenon. How can SALW smuggling could transpire in Malaysia? Crime involving the use of firearms may be unfamiliar to a large section of the population in the past. However, recent turn in crime trends with shootings, mafia like murders, planting of explosives in public areas seem to be on the rise recently despite the fact that Malaysian firearms laws (Note: The Firearms Act 1960 and the Firearms (Increased Penalties) Act 1971) are very strict especially pertaining to SALW ownership. This article would subsequently deliberate the definition of SALW whilst conduct comparison of its definition between Thailand, Indonesia and the Philippines, the three countries that share land and sea borders with Malaysia. Consequently discuss the factors affecting SALW smuggling to Malaysia.

In exemplifying the evidence in support of this article, on the ground research and fieldwork was conducted to ascertain the contributing factors for the continued propensity SALW smuggling into Malaysia especially at the Malaysia-Thailand border. Apart from on-site visits which involves observation and enforcement operations, interviews were conducted with both Malaysia and Thailand enforcement agencies, smugglers of firearms at the Malaysia-Thailand border, authentic moles who served as informer to Royal Malaysian Police (RMP) for those buying firearms in Thailand to smuggle into Malaysia. Crime desk journalists from major newspapers in Malaysia who were involved reporting smuggling activities at Malaysia-Thailand borders, members of recognized non-governmental organizations, prisoners under Section 3 and Section 8 of the Firearms Act 1960 and Firearms (Increased Penalties) Act 1971, former member of National Revolutionary Front (NRF) and former resident of Narathiwat were also interviewed. Secondary data were obtained from the credible reports and previous research that provided added foundational credibility of this article. 


\section{Definition of Small and Light Weapons (SALW)}

The definition offered in the United Nations 1997 Report of the Panel of Governmental Experts on Small Arms, explain that small arms consist of revolvers and self-loading pistols, rifles and carbines, assault rifles, sub-machine guns, and light machine guns. Light weapons include heavy machine guns, hand-held under-barrel and mounted grenade launchers, portable anti-tank and antiaircraft guns, recoilless rifles, portable launchers of anti-tank and anti-aircraft missile systems, and mortars of less than 100mm caliber (Small Arms Survey, 2002, p. 235).

As argued by Kramer (2001, p. 4), when discussing issues related to weapons and ammunition, there are no uniform term that could collectively be agreed among countries in the Southeast Asian region when discussing issues related SALW and ammunitions. Differences in these definitions amongst Southeast Asia nations were widely debated however due to the lack of harmonization of these firearm laws, little progress was made. These differences in the definitions also occur internally, at the domestic levels due to the inability to have a common agreement between civilian and military sectors. Here SALW generally refers firearms and ammunition that can be carried by one or two individuals. In this aspect Kramer interprets the definition as promulgated by the UN although it has not been accepted or applied universally.

"Small arms: revolvers and self-loading pistols, rifles and carbines, assault rifles, sub-machine guns, and light machine guns. Light weapons: heavy machine guns, hand-held under-barrel and mounted grenade launchers, portable anti-tank and anti-aircraft guns, recoilless rifles, portable launchers of anti-tank and antiaircraft missile systems, and mortars of less than $100 \mathrm{~mm}$ calibre. Ammunition and explosives: cartridges (rounds) for small arms, shells and missiles for light weapons, mobile containers with missiles or shells for single-action anti-aircraft and anti-tank systems, antipersonnel and anti-tank hand grenades, landmines, explosives (UN, 1997, para. 26). Explosives were further defined in the United Nations Report of the Group of Experts on the Problem of Ammunition and Explosives. The Group focused mainly on military high explosives, industrial explosives (including those used in the mining industry), improvised or 'home-made' explosives, and explosive initiators or detonators (blasting caps) (UN, 1999a, para. 16)'.

According to the definition offered by Stohl (2005, p. 60), SALW refers to firearms that can be carried by one or two persons, mounted on vehicles or stacked for delivery by animals. This classification is also used to illustrate machine guns to missiles including grenades and mortared rockets (rocket-propelled grenades (RPG).

The definition of SALW applied by Malaysia refers to the lethal rifled weapon that has the capability to discharge a projectile, ammunition or fired release, or which be customised to discharge any firing shot, bullet or other shot, and of any similar kinds of projectiles; and any kind of weapons designed or adapted or customised to release by fire any form hazardous liquids, gases or other objects, and this includes a rifle, windgun, automatic rifle and any component parts of any such weapon, and any added parts to the weapon which are designed or adapted to minimize the noise or emission of fires caused by firing the weapon [The 1960s Arms Act and the Firearms (Increased Penalties) Act 1971: 5]. In an easy to comprehend manner, SALW refers to the type of firearm that can be hand held. Included in this category are pistols, revolvers and also guns with long barrels (long guns) or shoulder guns such as rifles and shotguns. The heavy firearm refers to firearms that are not easily carried, handled or hand-handled by humans and should be placed on the ground or attached to something. Examples include weapons mounted on aircraft, tanks or artillery cannons. Normally these types of firearms are of caliber of more than $50 \mathrm{~mm}$. Illegal possession of firearms are interpreted as owning, safekeeping, protecting or in possession of firearms that is contrary to provisions under the Firearms Act 1960. Any invalid possession shall be considered as an offense, can be subjected to death by hanging or life imprisonment under the Firearms (Increased Penalties) Act 1971.

Comparison of SALW definitions among Indonesia, Thailand and Philippines, three countries that share the same land and maritime borders with Malaysia are further examined to clarify the differences. As scrutinized by Kramer (2001, p. 5), there is no dedicated definition of SALW in accordance with Indonesian firearms laws. As with Thailand, firearms include all weapons capable of delivering bullets through firing, pressured gas or compressed air or other mechanical designs that are very much reliant on the level of energy and use of restricted/controlled components that are placed under the authority of the Minister that are listed in the Ministerial Regulations.

While for the Philippines, the term firearms or weapons includes a rifle, musket, carbine, shotgun, revolver, pistol, and all other deadly weapons in which bullets, point ball, strokes, casings or other missiles may be released through explosive powder or any other form of explosives. The term also includes wind rifles except for small caliber with limited range that may be used as toys. Any barrel gun is also considered as a complete 
firearm and be subjected to law.

\section{Influencing External Factors of SALW Smuggling at the Malaysia-Thailand Border}

Off late the rise of serious criminal activities involving SALW such as gunfire and mafia murders using firearms and explosive materials in public places has been slowing increasing and becoming quite common. According to the former Deputy Prime Minister of Malaysia and Home Minister, Ahmad Zahid Hamidi who stated that the increase in crime cases in the country is believed to have been originated from firearm smuggling (Harian Metro, July 29, 2016). This scenario is alarming as it illustrates how easy firearms could be found on the black market and smuggled through our borders.

An UN expert panel defined the illegal sale of firearms as an international trade of conventional firearms that contravenes with the law of a country or international law (Marsh, 2002, p. 220; Capie, 2013, p. 90). Black market refers to the illegal movement of firearms by individuals, criminal groups or non-state actors such as rebel groups and often these three groups may be involved or work together. Black markets are considered illegal under the law of a country or international law and exist strong possibilities that these firearms be used for unacceptable purposes such as massacres, armed conflicts, human rights violations or planned criminal activities (Marsh, 2002, p. 223). Miani (2011: xviii) in his book defines the sale of smuggled firearm as illegal, in prohibition of the laws of the manufactured country, transfer, illegal for firearm or materials whose status that may be lawful in a country to be transferred to another country that is placed under restrictions by national or international law. As further clarified, the illegal transfer of firearms is also not accepted by most masses. It refers to the manufacture or transfer of firearms, the legal status of firearms or materials that are prohibited or the transfer to the disputed end user or its uncertain legal status (Miani, 2011: xix). According to Chouvy (2013, p. 90), illegal transfer of firearm could also be illustrated by the transfer of firearms from its legal owners (eg military or police) to groups or individuals who have no valid authority to possess them in the country.

Studies conducted by Kramer (2001, p. 2), Capie (2002, p. 94), Stohl (2005, p. 63), Iwa (2005, p. 1), Spapens (2007, p. 370), Kuhn and Bunker (2011) and Gagliardi (2012, p. 88) has collectively demonstrated firearm-smuggling activities have direct implications upon all types of organized criminal activities (as in smuggling and drug trafficking along with smuggling and human trafficking). The tradings of these activities are masterminded through illegal channels that may deem worthwhile and profitable initially until there exist an 'arms race' amongst these criminal groups. Bedeski, Andersen and Darmosumarto (1998, pp. 10-11) stated that the relationship between the spread of SALW and the criminal activities in Southeast Asia is very problematic further compounded by one of the principal contributing factors being the rampant pursuance of drug trade in the region. This finding is well argued, supported by a report alleging that SALW and drugs are often traded along lines of supply. Trade involving both SALW and drugs consistently complement each other, where the increase trade of one commodity would indirectly spur growth of the other commodity as well.

According to Capie (2002, p. 15), there exist five major factors that had triggered smuggling and firearm transfer within Southeast Asia. Firstly, the region had witnessed many internal conflicts and this has created a need of firearms through illegal sources by non-state actors. Secondly, the region is also the home to previous conflicts in several countries where a large number of military-owned SALWs that continue to prevail and are easily available. Thirdly, the geographical positioning of South-East Asia has very long maritime space and continental borders which are very difficult to conclusively patrol and monitor. Fourthly, this region is also the home to some 'weak states'. These are weak and inefficient political entities that have difficulties to effectively control its boundaries to stop the smuggling of weapons and $\mathrm{CBC}$ activities. These countries are also weak in managing, handling weapons inventory storage more often seen with unsafe and poorly managed facilities that are vulnerable to theft, loss and subsequent smugglings. Most of these countries do not have enough gun control and law enforcement mechanisms. Fifth and the final factor, despite the absence of conflict between countries in the region for more than two decades that has promulgated very encouraging regional development, nonetheless suspicion and distrust continue to prevail among Southeast Asian countries.

Through this study, it has revealed that the smuggling of SALW has made Malaysia a first direct recipient country of some these problems due to a number of external factors. The first external factor is the increase of SALW trading in the country is closely associated with the smuggling and drug trafficking activities from the Golden Triangle (Myanmar, Laos and Thailand), the second largest producer in Asia. In a preliminary interview with Khalid bin Abu Bakar, the former Inspector General of Police (IGP) on 21st March 2016, it was revealed that following some extensive investigations by the RMP, findings rather decisively indicate in most SALWs seizures, these weapons are mostly smuggled through the Malaysia-Thailand border. These SALWs are not meant for transit purposes but mostly destined for use in Peninsular Malaysia for various purposes such as 
smuggling and drug trafficking, secret societies, gambling and vice activities, gangterism, thugish groups to be armed with firearms, armed robberies, assassinations and other organized criminal activities which are all unlawful. According to the prisoners under Section 3 and Section 8 of the Firearms Act 1960 and Firearms Act (Increased Penalties) 1971 Malaysia who commit armed robbery, unlicensed possession of weapons, drug trafficking and gangsterism, attest the convenience of obtaining SALW through black market in Thailand (Danok, Golok and Padang Besar). Among the lucrative variants of SALW purchased, popular among perpetrators of these three prisoners are K3.8 Auto Smith \& Wessen, M1191 and US-made Glock that could easily purchase at a price between RM1500-RM4000 including a box of ammunition. Though within the bracket but the price could differ, given the type and condition of the SALW (Interview: Ah Hoe, Tokeh and Ah Yee [non-real name] March 21, 2018, April 24, 2018 and April 25, 2018 respectively). IGP's statement that most of these SALWs were smuggled from northern Peninsular coupled with statistics from a few SALWs raids in East Malaysia were well substantiated in Capie's work (2002, p. 54). Capie (2002, p. 55) also argued that illegal SALWs activities along the porous boundaries between East Malaysia and the Philippines indirectly compel the fishermen to be armed for their defense against pirates. As decendants of the land, these fishermen do not follow the immigration formalities due to their daily travel, use of easy entry routes between the Malaysia-Philippines border. Capie stated investigation undertaken by a researcher in Kuala Lumpur reveal there was little conduct of SALWs smugglings as there exist barter system between Sabah and the Southern Philippines whereby fish or logs are exchanged with firearms from insurgents in southern Philippines. In discussing such avenues in West Malaysia, Penang Port was disclosed as a smuggling point that includes SALWs from Cambodia and Thailand. An established Berita Harian newspaper crime desk journalist who has contributed special report of smuggling activities at the Betong (Thailand)-Pengkalan Hulu (Perak, Malaysia) in 2009 attested that apart from the land routes, smuggling of SALWs are also pursued through maritime avenues. Apparently this is not something new as waterways were used since Au Siang of Thailand triad activities. SALW was smuggled through the waters of Kuala Sepetang, Lumut and Kuala Gula under disguise of fishing boats. These SALW smuggling activities were especially confined within the vicinity of the Thailand-Perlis, Thailand-Kelantan and Thailand-Perak borders. Though a majority of these smuggled weapons are for the Malaysian market, notwithstanding Malaysia also serves as a transit point for other lucrative destinations as in Indonesia, Singapore and Philippines with the Andaman Sea and the Straits of Melaka being the main passage waterway (Interview: Che Mad [non-real name, April 8, 2018). As for SALW smuggling at Rantau Panjang, Kelantan, information sourced from the SALW smuggler indicate that these weapons are procured from Thailand via Sungai Golok. It was reported that members of the Thai Police are also a party to this lucrative industry of selling SALW (Interview: Pok Lan [non-real name], April 22, 2018). These privy information was also substantiated by other SALW smugglers at neighbouring Bukit Kayu Hitam-Danok border and Pengkalan Hulu-Betong who added these weapons are either smuggled through the border gates or illegal openings in the fences, the determination depends which offers compromise of security at that point of time (Interview: Hasan bin Abu [non-real name], the smuggler of Laka Temin village, April 11, 2018 and Che Ann [non-real name], Pengkalan Hulu smuggler, April 14, 2018). Sourcing of data and research with the Malaysian Maritime Enforcement Agency (MMEA) on August 5, 2018, offers the smuggling hotspot trajectory that includes SALW on the Malaysia-Thailand border in the area around the seas of Langkawi Island and subsequently entering the coastal states of Peninsular Malaysia and neighbouring countries is shown in Figure 1.

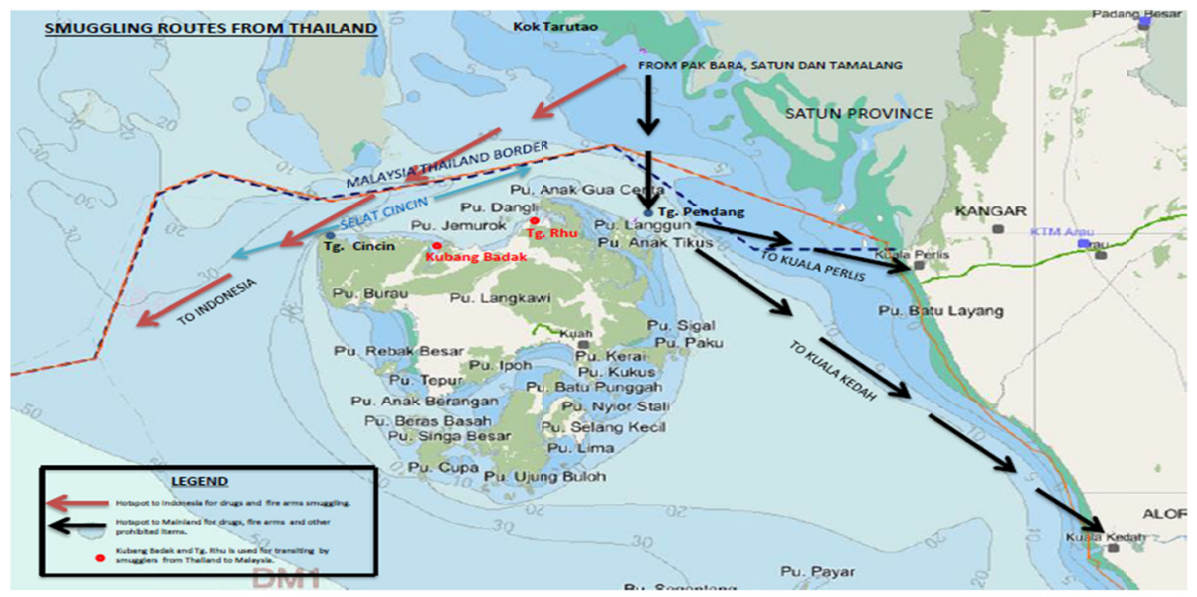

Figure 1. Maritime Smuggling Hotspot Route at North Peninsular Malaysia-Thailand Border Source: Researcher Illustration 
For decades the region had its fair share of ongoing war and armed conflicts as witnessed in Vietnam, Thailand, Indonesia, Myanmar, Cambodia and the Philippines thus this represents the second external factor that contributes to the increase SALW smugglings into Malaysia. As pointed out by Kartha (1999: 1450-1460), it is known fact that civil war within the Asian region had its spillover effects in terms of refugees, firearms and national alliance activities. Capie $(2002$, p. 41) stated that these internal conflicts, inter-national conflicts and conflicts in the country were mainly due to external interferences into the region. A large number of these SALWs have been smuggled for the Aceh Merdeka Movement through southern Thailand through the Penang Port in Malaysia which has a large Acehnese population. Most of these weapons are believed to have originated from Cambodia. There have been reports that smuggling through southern Thailand is done with help of the Pattani United Liberation Organization (PULO), a Thai separatist group. Southeast Asia is the cross roads for smuggling and distribution of firearms. According to a report by GunPolicy.Org, Thailand is seen as the main destination for black market trading of firearms in Southeast Asia followed by Cambodia and Vietnam. Kramer (2001:1) concurred that the growth of SALW dealings with minimum control in Southeast Asia has threatened the security of the people and the country, indirectly emerge as stumbling block for development and contributes to increased crime. Based on the civilian firearms ownership in 178 countries, Table 2 demonstrates civilian firearms ownership per 100 inhabitants of listed Southeast Asia countries on this subject. Thailand leads this association with 15.6 weapons for every 100 people.

Table 2. The largest civilian firearms arsenals (ranked by averaged rate of civilian ownership, guns per 100 people)

\begin{tabular}{|c|c|c|c|c|c|c|c|c|c|}
\hline Country & $\begin{array}{c}\text { Rank by } \\
\text { rate of } \\
\text { ownership }\end{array}$ & $\begin{array}{c}\text { Average } \\
\text { firearms } \\
\text { per } 100 \\
\text { people }\end{array}$ & $\begin{array}{c}\text { Low } \\
\text { firearms } \\
\text { per } 100 \\
\text { people }\end{array}$ & $\begin{array}{c}\text { High } \\
\text { firearms } \\
\text { per } 100 \\
\text { people }\end{array}$ & $\begin{array}{l}\text { Average total } \\
\text { all civilian } \\
\text { firearms }\end{array}$ & Low total & High total & Registered & $\begin{array}{c}\text { Population, } \\
2005\end{array}$ \\
\hline Thailand & 39 & 15.6 & 15.6 & 15.6 & 10000000 & 10000000 & 10000000 & 3870000 & $64^{\prime} 232^{\prime} 800$ \\
\hline Philippines & 105 & 4.7 & 3.4 & 6.0 & 3900000 & 2800000 & 5000000 & 775000 & $83^{\prime} 054^{\prime} 500$ \\
\hline Cambodia & 109 & 4.3 & 2.1 & 6.4 & 600000 & 300000 & 900000 & & $14^{\prime} 071^{\prime} 000$ \\
\hline Myanmar & 111 & 4.0 & 4.0 & 4.0 & 2000000 & - & - & - & $50^{\prime} 519^{\prime} 500$ \\
\hline Vietnam & 128 & 1.7 & 1.7 & 1.7 & 1100000 & - & - & - & $83^{\prime} 119^{\prime} 000$ \\
\hline Malaysia & 133 & 1.5 & 1.5 & 1.5 & 370000 & 142038 & & & $25^{\prime} 347^{\prime} 400$ \\
\hline Brunei & 137 & 1.4 & 1.4 & 1.4 & 5400 & 5400 & 5400 & - & $373^{\prime} 900$ \\
\hline Laos & 145 & 1.2 & 1.2 & 1.2 & 71000 & & - & - & 5'924'200 \\
\hline Indonesia & 169 & 0.5 & 0.5 & 0.5 & 1000000 & 1000000 & 1000000 & 34150 & $220^{\prime} 558^{\prime} 000$ \\
\hline Singapore & 169 & 0.5 & 0.5 & 0.5 & 22000 & 22000 & 22000 & - & 4'341'800 \\
\hline $\begin{array}{l}\text { Timor } \\
\text { Leste }\end{array}$ & 177 & 0.3 & 0.3 & 0.3 & 3000 & - & - & - & $950^{\prime} 000$ \\
\hline
\end{tabular}

Source: Chapter 2, Annexe 4, Small Arms Survey 2007

Malaysia's strategic position on these important maritime trading routes which is further compounded with shared land and maritime boundaries with some countries that are facing such armed conflict has indirectly paved the reasoning for an increase of SALW smuggling activities. Malaysia as a country in the middle of this 'smuggling ring' is saddled with and has to dwell, face various problems arising from this situation (Ruhanas, 2009, p. 20). Armed conflict in neighboring countries is viewed as one of the main indirect causes of SALW access to the people and Malaysia's security is thus subjected to the political, social and economic instability due to these offshoot effects of the conflicting country. Following the outbreak of armed rebellions and insurgencies had resulted in widespread increase in smugglings and grave misuse of SALW that in some stages is beyond control. Increased smuggling of firearms in Southeast Asia would pose serious intimidations to ASEAN's political, economic, social and moral well-being (Iwa, 2005, p. 2). The interview with Ayob Khan, Principal Assistant Director, Counter Terrorism, Bukit Aman Special Branch on July 27, 2018, said the terrorist activities cannot be isolated from smuggling of SALW. The porous borders of Malaysia-Thailand, is a sad reality that facilitates various smuggling activities including SALW. The emerging influence of these Islamic State (IS) group as militant group and DAESH, the Jemaah Islamiah Group (JI), the Malaysian Militant Group [KMM] (formerly known as the Kedah Mujahidin Group [KMK]) and Darul Islam (DI) terrorism that operates in Malaysia where KMK banner readily obtains SALW supplies from southern Thailand. Ayob Khan further added that discovery following several incidents such as the murder of Joe Fernandez, Lunas State Assemblyman, Kedah in 2000, the robbery of Southern Bank, Petaling Jaya in 2001, a bomb blast at Movida night club, 
Puchong in 2016, that M16 firearms and explosives from the Vietnam War (1964) were used and these were smuggled out of Thailand. Crime desk journalist of Harian Metro believes there is a possibility of separatist groups in southern Thailand such as PULO and others are the agents who provide SALW in support of terrorist operations in Malaysia. He added that the entry of Pattani people into Malaysia for food business purposes should be given further scrutiny and investigated. These is every possibility that such innocent human traffic of Thai citizens provide sound platform for SALW smuggling tactics as well as other illegal goods taking into account his experience of reviewing the separatist faction's movements and tactics in Pattani in 2016 (Interview: Chik [non real name], April 5, 2018). A former member of the 30-years veteran of the National Revolutionary Front (NRF) separatist group, who has been residing in Kelantan, Malaysia for almost 10 years, confirms that different makes of SALW are easily available in Thailand. Most popular and readily available are the US-made SALWs that can be purchased for as little as RM1500 on the black market. According to him, SALW is widely used by secret societies, gangsters as well as separatist groups in Thailand. There are also SALWs sold openly, available over the counter at licensed stores around Bangkok, Hatyai and Songkla. Apart from that, the legitimate sale of own SALWs by the Thai police and soldiers to the general public also occurs as they were licensed to buy and own firearms other than those supplied by the Government. There is hardly any denial in the conduct of rampant SALW trafficking from Thailand into Malaysia especially through Sungai Golok (Interview: Pok Chai [non-real name], April 22, 2018). Kuala Lumpur Deputy Police Chief also concurred there was an increase in the use of fully automatic SALWs such as sub-machine guns and rifles as evident in recent murder of Palestinian lecturer in Setapak, Kuala Lumpur and random shooting cases at entertainment outlets both in Taman Maluri and Bukit Bintang, Kuala Lumpur in 2018 (Interview: Zainuddin Yaacob , August 14, 2018).

The third factor is the dumping of post-war SALWs in neighboring countries such as Vietnam and Cambodia. According to Capie (2002:15), several countries in the region had witnessed conflicts where a large number of military-owned SALWs were conveniently disposed and since made easily available. In his research, Capie has further claimed that after the fall of South Vietnam in April 1975, a large number of abandoned United States (US) supplies were seized by the North Vietnamese army with an estimated haul of between 1.5 million to 1.8 million SALWs and 150,000 tons of ammunition. These include 90,000 pistols of M1911A1, 791,000 pistols of M15A1s, 857,580 rifles, 15,000 M50 machine guns and 47,000 of IN879 grenade launchers. Many of these weapons were then sold by the Vietnamese government to its allies but implicated these sales were undertaken by terrorist groups. Similarly, Cambodia is believed to have between 500,000 and 1,000,000 military-style firearms spread throughout the country after the collapse of the previous government. These firearms were smuggled through southern Thailand via the Straits of Malacca to Aceh. On the same vein, Cambodian firearms were also smuggled into Thailand, Indonesia, Myanmar, India, the Philippines, Sri Lanka and other countries. Cambodia served as an important source of firearm supplies for countries facing internal conflicts due the avalanche left over following post-civil war. This indirectly propelled Cambodia as a warehouse of firearms stockpiling, attracting brokers and firearms distributors who are looking for light military hardware at low cost. These individuals have been helped in their business by law enforcement agencies receiving bribes and Thai military personnel who exercised relaxed enforcement at border crossing points. When these SALWs enter Thailand, it will be supplied to criminal groups or sent out via land or sea route to markets in Myanmar, Sri Lanka or Indonesia. Thailand is surrounded by neighboring nations saddled with insurgents and ongoing conflicts thus made it a condusive center for firearm brokers and SALWs transfers. Miani (2011: 42) also agreed that stocks of firearms originated from Cambodian and Myanmar were supplied to conflict zones such as Aceh, Sri Lanka, southern Thailand, north-eastern India and to the Thai-Myanmar border. As has contested as the second factor, the geographical position of Malaysia, conflict consequences in neighboring countries provide favourable probability and momentum for an escalated smuggling of SALWs by organized crime groups within the country. In an interview with Royal Thai Border Patrol Police, it was also established that there exist a very strong possibility of stockpiles of SALW from the Vietnam and Cambodia war being smuggled into Thailand. These weapons subsequently made available in the very profitable black market trade would be for internal use of crime in Thailand or on transit to other foreign countries. Undeniably most of these SALWs have also been smuggled into Malaysia (Interview: Abdul Hakim Che Mut, April 22, 2018).

SALW sales are seen as a very profitable enterprise. This fourth factor is also one of the causes that stimulate the smuggling SALW. Capie (2002, p. 20) stated that the transactions involving trading SALW is acclaimed as the second most profitable business and a large number of arms from Cambodia, southern China and Vietnam have been smuggled with the knowledge and active involvement of Thai and Cambodian soldiers as well as politicians. Gagliardi (2012, p. 88) also agreed that due to the exceptionally huge profits acquired from SALW sales, the criminals are willing to do anything for the sake of greed, dominance, revenge and ideology. These monetary gains are the main motivations for SALW smuggling (Capie, 2013, p. 92). From Malaysia's 
perspective, the monetary motivator supercedes the risk, though it is difficult to obtain SALW in the country, however the expensive price makes the peril worth encountering. So, it is not surprising for SALW smuggling to transpire into the country by non-state actors for various purposes. A non-governmental organization representative of the Malaysia Crime Prevention Foundation (MCPF) to a certain extent supports, does not deny that the ongoing SALW smuggling due to a host of reasons as in favourable markets, the ever-increasing demand of this commodity from within the country, the absence of advanced, modern SALWs and the lack of SALW resources in the country that inevitably compel flouting non-state actors to rely on the black market. The acquisition SALW is synonymous with Thailand as it is the most convenient, cheapest and readily available source (Interview: Kamal Afendi Hashim, May 24, 2018).

SALW smuggling would not occur if there is no demand or supply. This fifth factor also contributes to the increase of SALW smuggling cases into the country. An estimate of 639 million SALWs are in circulation around the world. So supply is not viewed as an issue (Stohl, 2005, p. 61). South East Asia has available stock for purchase. SALW is also durable and has a longer life span. A report by Keith Krause (July 2000) indicated unlike conventional weapons, most SALW sales are recycled and not newly manufactured (Capie, 2013, p. 92). From the perspective of demand, with the occurrence of conflicts in the region has created the necessity for illegal SALW among insurgent groups and other non-state actors. There are also sophisticated local and transnational criminal networks involved in various illegal activities including drug trafficking, human trafficking, money laundering, forgery and extortion (Capie, 2013, p. 91). This disclosure is enough to illustrate the demand for insurgents and criminals to be armed with SALWs. Among the most sought after SALWs are the Soviet-made AK47 rifles, the Chinese made Type 56, US made M16 and AR15s rifles, the Soviet-made SKS, weapons from World War II era as in the US-made M1s, carbine and M14 automatic. Additionally, US-made grenade launchers M203 and M79 are also in good demand (Capie, 2002, p. 26). According to Bedeski, Andersen and Darmosumarto (1998, p. 7), Vietnam is sought for the supply of SALW in the region. The SALW seizure obtained from Vietnamese fishermen (as some fishermen are former military personnel) in the South China Sea provides evidence of the uncontrolled movement of old military wares from military owned stores by militants consequently be smuggled into neighboring countries as there is a demand for such firearms from Vietnam. As in the case of Cambodia, there has been an increase in SALW demand among its citizens who feel insecure, no longer have guaranteed security and ultimately require these weapons for self-defense. This indirectly provide irrefutable evidenced that following incidents surrounding the coup in 1997 had resulted in further violence and failure of the UN security mission. According to a reliable Thai informer who is in established, close association with the RMP, who in-turns undertakes smuggling of various illegal goods, without reservation confirmed that each month there are a minimum of 4 shipments of SALWs to Malaysia with each shipment consisting of two or three weapons. In this case, most of the SALW supply are attained from Patthalung, Thailand. He further added that additional supplies could be sourced from Songkhla, Padang Besar, Danok, Narathiwat and others. What that is crucial here is the demand, to meet the buyer's specifications and it must be supplied within the short time frame. He added that most of the customers were Malaysian gangsters with the majority of the buyers being Indians and Chinese (Interview: Rae Wat [non-real name], August 9, 2018).

For the sixth factor, as discussed by many scholars' among others Kartha (1999), Capie (2002), Misalucha (2004), Alusala (2010), Miani (2011), Denik (2012) and Zohar (2015), generally agree armed conflict and insurgency contribute towards increased SALWs smuggling and Malaysia is no exception to the direct repercussions of these illegal activities. According to Capie (2002, p. 20), the main source of SALW's for a majority of armed conflicts in the region are supplied from Indochina, especially from Cambodia, Vietnam and Laos. These destinations has emerged as the main transit of arms supplies from southern China. Thailand has slowly emerged as the prime center for illegal SALW brokerage and facilitator of illegal transfer with Cambodia as the last transit destination, main source of supplies. Large caches of post-war firearms had made it a very enticing source for brokers at low prices that may ignite continued smuggling activities. Illegal SALW supplies to Thailand will be distributed to local criminals or exported out to Burma, Sri Lanka or Indonesian markets. Previously Thailand reigned as the main pipeline of SALWs supply to the grey market as to the Khmer Rouge and other fighting groups in Cambodia. Capie (2002, p. 88) added that today Thailand has since emerged as the leading SALWs black market supply center from Cambodia to the insurgents in Myanmar, Acheh, Sri Lanka and northeast India. Surrounded by neighbours facing internal conflicts and insurgents, Thailand has become the main center of brokerage and facilitating SALWs transfers (Capie, 2002, p. 92). Miani (2011, p. 42) has also agreed that the Chinese-owned SALWs stocks in Cambodia and Myanmar have also been supplied to conflict zones such as Acheh, Sri Lanka, southern Thailand, northeastern India and the Thai-Myanmar border. During the Cold War, there was an over supply of SALWs from the US, China, Cuba, former Czechoslovakia, France, Thailand, Singapore, Vietnam, and Soviet Union that flooded Cambodia. Based on statistics gathered by the 
United Nations Authority in Cambodia (UNTAC) in 1993, it was estimated that 320,443 SALWs and 80.7 million rounds of ammunition were owned by opposition (Capie, 2002, p. 28). Usually, the choice of SALW is a favoured option for armed conflict because it is easy to carry, easy to use, affordable and difficult to detect (Misalucha 2004: 132). The Royal Thai Marine Police in Tak Bai in turn contested that SALW that were traded in the black market in Thailand were likely either from Myanmar or Laos which is very much in line with previous scholarly studies. It is deduced that shipment is made possible via the Thai-Myanmar land border through Chiang Mai and additionally through the waterways of Ranong, Andaman Sea. This is further made possible due to the tight territorial tussle between the drug cartel group and the existence of guerillas on Myanmar-Thailand border of which the Myanmar government are having difficulty exercising control (Interview: Wacharat Meangpracha, April 19, 2018). According to a reliable Thai informer to RMP, SALW in the Thai black market is derived from Songkhla, Nakhon Si Thammarat and Patthalung. SALWs smuggled into Thailand are most derived from Cambodia and other countries including China. For SALW that are purchased by Malaysians, these would smuggled through illegal entry avenues through Malaysia-Thailand border area near Chai Kuan (Thailand) and thick vegetation of Felda Rimba Mas, in Malaysia (Interview: Longkorn [non-real name], August 7, 2018). According to another informant Rae Wat's acquired on August 9, 2018, SALW is cheap and thriving in Narathiwat due to the ongoing upheaval between separatist tribes in the three southern provinces of Thailand namely Yala, Narathiwat and Patani. As expressed by former residents of Narathiwat who is now living and working in a restaurants in Kuala Lumpur, the long drawn tribal conflict is ever rampant occurring in Tanjung Mat, Narathiwat such as Kampung Cho-Airong, Kampung Bongo and Kampung Dusun Nyior (Interview: Aung [non-real name], April 26, 2018). Malaysia and Thailand is tucked between these conflicting countries is very much impacted by the domestic upheavals of its neighbours.

The seventh factor which is considered among the crucial cause of escalating SALWs smuggling is due to the weakness of the international legal framework. Through Kramer's work (2001), has divulged that many of Southeast Asian country's domestic firearms control legislations are not uniform with varying different definitions of SALWs. Some of states only exercise control through administrative instructions, proclaimations or declarations and not any legalised bylaws. These observations are also supported by Bedeski, Andersen and Darmosumarto (1998:5) who added exist a serious flaw in the absence of any formal agreements at the regional or international level as to exercise control of SALWs whether it be legitimate or illegitimate dealings. Prevailing unclear regulations or ineffective domestic laws relating to SALW purchases do contribute to an increase in the quantity especially in black market tradings. Furthermore if the individual purchase quantity limits are to set or agreed, there would inevitably be 'straw purchases' where individuals can buy in large quantities and resell them. The sale of illegal SALWs usually occurs across international borders of countries with loose firearm laws into countries with strict firearm laws (Stohl 2005:63). International legal framework favours the brokers as since it being poorly developed indirectly permitting the financing and brokerage of illegal SALW sales. For Malaysia, the application of loose firearms laws in addition to the many different interpretations of SALW coupled with the geophysical position situated among many countries with relatively equally relaxed firearm laws offers viable openings for non-state actors in the country seek ever available and cheap supplies from its neighboring countries. The enforcement of firearms provisions in Malaysia namely the Firearms Act 1960 and the Firearms Act (Increased Penalties) Act 1971 are very rigidly strict that is punishable with the mandatory death penalty in the event of committing such an offence of firing and that may cause death. However, there appear to be distinct prioritization on the severity of offences on both sides of the border as evidenced from interviews with Thai security personnel informants (Betong Police Chief Torsak Sareeruth, Betong Deputy Chief of Police Paramet Plabplueng, Betong Thai Border Patrol Police Chetvit Neerahing, April 14, 2018, Deputy Khoudon Satun Police Chief, Chan Chutirat, April 12, 2018, Tak Bai Thai Marine Police Wacharat Meangpracha April 19, 2018, Golok Thai Border Patrol Police Abdul Hakim Che Mut, veteran of NRF, Pok Chai [non-real name] April 22, 2018, both informers Longkorn's [non-real name] August 7, 2018 and Rae Wat [non-real name] August 9, 2018 and former residents of Narathiwat Aung [non-real name] April 26, 2018 who almost conclusively agree the execution of Thai firearms provisions are not as strictly enforced as binding as a law as apparent in Malaysia. Through this research it was understood from Chan Chutirat, Khoudon's Deputy Chief of Police, though there is a provision for the use of the death penalty clause under the Thai law but this is very much reliant on the Court. All informants conclude that in most cases a fine is normally imposed if the offender claims to have a gun without a license or deemed to have used. Seldom is a jail sentence imposed. Thai firearm law permits the people to own firearms for the purpose of self-defense, safeguarding personal property, sports or hunting. (Xinhuanet.com., October 13, 2017).

In addition, the eighth factor is a consequence to the lack of dedicated cooperation among countries that invite a strong cause of increased smugglings of SALWs. According to preliminary interviews with Huzir Mohamad of 
RMP on the 23 March 2016 along with Somyot Srisorayut Royal Thai Police in Kuala Lumpur on 26 December 2017 collectively state there is a lack of access and sharing of necessary information from the relevant agencies for both CBC and SALW activities. This was also mentioned picked up by Bedeski, Anderson and Darmosumarto (1998:5) as the lack of coordination and cooperation among regional partners in an effort to curb circulation and supply of SALWs from within and outside the region. Further dissecting the crux, though the modus operandi used by the smugglers may be similar, but the lack of enforcement capacity by individual states and regional cooperation to address the challenge of this SALW (Capie, 2002, p. 26).

\section{Conclusions}

The unchecked use of SALW raises the concerns about the increase in smuggling activities, use of explosives and ammunition in Malaysia that presents the conditions of inviting terrorism related activities, unauthorized use of firearms that would inevitably contribute towards insecure environment meshed with a rising crime rate in the country. On a study conducted by scholars, it is apparent that domestic and external factors have an influential factor that increases SALW smuggling into Malaysia and its related crime committed by non-state actors. The government must ensure that national security is preserved without neglecting the safety of people as this in-turn contributes towards economic, political and social stability as well as the development of nationalistic ideas. Additionally, the government should embrace the aspect of whole human security, the community and the country and institute proper control mechanisms so as to maintain its territorial integrity to ensure national security. It is important that the government always be far-sighted and be prepared to deal with security issues, especially in addressing SALW smuggling, movement of ammunition and explosives. In an impending environment minus any borders, if such possible instable scenarios are left unchecked it may spiral into more damaging circumstances, creating much fear and strife among the population. There would be no national security if there is no public order. There can be no public order if the governing government fails to maintain national order to ensure human security and national security is always safeguarded.

\section{References}

Abu Bakar, K. (2016). Inspector General Police. Bukit Aman, Kuala Lumpur.

Abu, H. (2018). Bukit Kayu Hitam Smuggler. Kedah, Malaysia.

Ah Hoe. (2018). Prisoner. Bentong Prison, Pahang.

Ah Yee. (2018). Prisoner. Kajang Prison, Kuala Lumpur.

Aung. (2018). Former Residents of Narathiwat. Kuala Lumpur, Malaysia.

Bedeski, R. E., Andersen, A., \& Darmosumarto, S. (1998). Small Arms Trade and Proliferation in East Asia: Southeast Asia and the Russian Far East (pp. 1-33). Institute of International Relations, University of British Columbia.

Capie, D. (2002). Small Arms Productions and Transfers in Southeast Asia. Australia: Strategic and Defence Studies Centre Australian National University.

Capie, D. (2013). Arms Trafficking in Mainland Southeast Asia. In P. Chouvy (Ed.), An Atlas of Trafficking in Southeast Asia: The Illegal Trade in Arms, Drugs, People, Counterfeit Goods and Natural Resources in Mainland Southeast Asia (pp. 89-112). London and New York: I.B Tauris \& Co Ltd.

Che Ann. (2018). Pengkalan Hulu Smuggler. Perak, Malaysia.

Che Mad. (2018). Berita Harian Journalist. Kuala Lumpur, Malaysia.

Che Mut, A. H. (2018). Royal Thai Border Patrol Police. Golok, Thailand.

Chik. (2018). Harian Metro Journalist. Kuala Lumpur, Malaysia.

Chouvy, P. (2013). Introduction: Illegal Trades across National Borders. In P. Chouvy (Ed.), An Atlas of Trafficking in Southeast Asia: The Illegal Trade in Arms, Drugs, People, Counterfeit Goods and Natural Resources in Mainland Southeast Asia (pp. 1-28). London and New York: I.B Tauris \& Co Ltd.

Chutirat. C. (2018). Royal Thai Police. Khoudon, Satun, Thailand.

Emmers, R. (2003). ASEAN and the securitization of transnational crime in Southeast Asia. The Pacific Review, 16(3), 419-438. https://doi.org/10.1080/0951274032000085653

Gagliardi, P. (2012). Transnational organized crime and gun violence. A case for firearm forensic intelligence sharing. International Review of Law, Computers \& Technology, 26(1), 83-95. https://doi.org/10.1080/13600869.2012.646801 
Global Impact of Gun Violence.Armed Violence and Guns in South East Asia. GunPolicy.Org. Retrieved from http://gunpolicy.org/firearms/region/south-east-asia

Global Study on Homicide. Homicide counts and rates, time series 2000-2012. United Nations Office on Drugs and Crime Homicide Statistics. (2013). Retrieved from http://www.unodc.org/gsh/en/data.html

Griffiths, H. (2010). The Globalization of Crime a Transnational Organized Crime Threat Assessment. United Nations Office On Drugs and Crime.

Harun, R. (2009). Peningkatan Keselamatan Bersama Melalui Kerjasama Duahala Malaysia Dan Negara-Negara Jiran. JEBAT: Malaysian Journal of History, Politics and Strategic Studies, 36, 16-40.

Ismail, R. A. (2016, July 29). Op Cantas Khas 2.0 Tingkat aktiviti pembanterasan jenayah. Harian Metro, p. 22.

Iwa Mulyana. (2005). The Issue of Small Arms and Light Weapons (SALW) in the Context of Trans-National Organized Crime: Its Implications for Asean Security. Beijing: UN Workshop on SALW. Retrieved from http://www.poa-iss.org/RegionalOrganizations/ASEAN/The\%20Issue\%20of\%20SALW\%20in\%20the\%20c ontext $\% 20 \mathrm{of} \% 20$ transnations $\% 20$ organized\%20crime.pdf

Jomo K. S., \& Khoo, K. J. (2002). Globalization and its discontents. New Delhi: Tulika.

Kartha, T. (1999). Trans - national crime and light weapons proliferation: Security implications for the state. Strategic Analysis, 23(9), 1449-1466. https://doi.org/10.1080/09700169908455136

Kramer, K. (2001). Legal Controls on Small Arms and Light Weapons in Southeast Asia. Geneva: Small Arms Survey: A joint publication of the Small Arms Survey and Nonviolence International Southeast Asia. Retrieved from https://www.ciaonet.org/attachments/8597/uploads

Kuhn, D., \& Bunker, R. (2011). Just where do Mexican cartel weapons come from?. Small Wars \& Insurgencies, 22(5), 807-834. https://doi.org/10.1080/09592318.2011.620815

Longkorn. (2018). Informer. Padang Besar, Thailand

Lumpe, L., Meek, S., \& Naylor, R. (2000). Introduction to Gun-Running. In L. Lumpe (Ed.), Running Guns the Global Black Market in Small Arms (pp. 1-10). United Kingdom: Zed Books Ltd.

Markowski, S., Koorey, S., Hall, P., \& Brauer, J. (2009). Multi-Channel Supply Chain For Illicit Small Arms. Defence And Peace Economics, 20(3), 171-191. https://doi.org/10.1080/10242690802030903

Marsh, N. (2002). Two Sides of the Same Coin? The Legal and Illegal Trade in Small Arms. The Brown Journal of World Affairs, 9(1), 217-228. https://www.jstor.org/stable/24590286

Mc Evoy, C., \& Hideg, G. (2017). Global Violent Deaths 2017: Time to Decide. Geneva, Switzerland: Small Arms Survey. Retrieved from http://www.smallarmssurvey.org/fileadmin/docs/U-Reports/SAS-ReportGVD2017.pdf

McGrew, A., \& Lewis, P. (1992). Global Politics. England: Cambridge, Polity Press.

Meangpracha, W. (2018). Royal Thai Marin Police. Tak Bai, Thailand.

Miani, L. (2011). The Sulu Arms Market: National Responses to a Regional Problem. Singapore: Institute of Southeast Asian Studies.

Misalucha, C. (2004). Failures at the National Level: The Diffusion of Small Arms and Light Weapons in the Philippines. Philippine Political Science Journal, 25(48), 131-148. https://doi.org/10.1080/01154451.2004.9754260

Mohamed, H. (2016). Deputy Director Crime Investigation Department (Organized Crime). Pusat Latihan Polis (PULAPOL), Kuala Lumpur.

Muggah, R., \& Moser-Puangsuwan, Y. (2003). Whose Security Counts? Participatory Research on Armed Violence and Human Insecurity in Southeast Asia Armed Violence and Human Insecurity in Southeast Asia. Geneva and Bangkok: Small Arms Survey. Retrieved from http://www.smallarmssurvey.org/fileadmin/docs/ E-Co-Publications/SAS-NI-2003-whose-security-counts.pdf

Neerahing, C. (2018). Royal Thai Border Patrol Police. Betong, Thailand.

Obstructing Development: The Effect of Small Arms on Human Development. Small Arms Survey. (2003). Geneva. Retrieved from http://www.smallarmssurvey.org/fileadmin/docs/AYearbook/2003/en/Small-ArmsSurvey-2003-Chapter-04-EN.pdf

Plabplueng, P. (2018). Royal Thai Police. Betong, Thailand. 
Pok Chai. (2018). Former Member of National Revolutionary Front. Kelantan, Malaysia.

Pok Lan. (2018). Kelantan Smuggler. Kelantan, Malaysia.

Rae Wat. (2018). Informer. Padang Besar, Thailand.

Sareeruth, T. (2018). Royal Thai Police. Betong, Thailand.

Shing Huei, P. (2016, February 18). Thailand has highest reported rate of gun-related deaths in Asia: Report. Channelnewsasia. Retrieved from https://www.channelnewsasia.com/news/asiapacific/thailand-has-highestreported-rate-of-gun-related-deaths-in-asia-8171308

Spapens, T. (2007). Trafficking in Illicit Firearms for Criminal Purposes within the European Union. European Journal of Crime, Criminal Law and Criminal Justice, 15(3), 359-381. https://doi.org/10.1163/092895607x231206

Srisorayut, S. (2017). Royal Thai Police. Information sharing on weapon smuggling statistics and criminals between Thailand-Malaysia. Ipoh, Perak.

Strengthening Controls: Small Arms Measures. Small Arms Survey. (2002). Geneva. Retrieved from http://www. smallarmssurvey.org/fileadmin/docs/A-Yearbook/2002/en/Small-Arms-Survey-2002-Chapter-06-EN.pdf

The Firearms Act 1960 and Firearms (Increased Penalties) Act 1971. (2015). Selangor, Malaysia.

The Small Arms Survey 2007: Guns and the City. Small Arms Survey (2007). Geneva. Retrieved from http://www.smallarmssurvey.org/fileadmin/docs/A-Yearbook/2007/en/Small-Arms-Survey-2007-Chapter-0 2-annexe-4-EN.pdf

Tokeh. (2018). Prisoner. Kajang Prison, Kuala Lumpur.

Weapons and Markets. Small Arms Survey. Geneva. Retrieved from http://www.smallarmssurvey.org/weapons-and-markets.html

Williams, P., \& Black, S. (1994). Transnational threats: Drug trafficking and weapons proliferation. Contemporary Security Policy, 15(1), 127-151. https://doi.org/10.1080/13523269408404060

Xinhuanet. (2017). Newly amended law bans foreigners from using, owning guns in Thailand. Retrieved from $\mathrm{http}: / /$ www.xinhuanet.com//english/2017-10/13/c_136675426.htm

\section{Copyrights}

Copyright for this article is retained by the author(s), with first publication rights granted to the journal.

This is an open-access article distributed under the terms and conditions of the Creative Commons Attribution license (http://creativecommons.org/licenses/by/4.0/). 